\title{
The Extent and Compulsions That Motivated the Military to Take Over Political Power in Bangladesh
}

\author{
Shelim sheik ${ }^{1}$, WANG Guohua ${ }^{2}$, and Kamrun Nahar ${ }^{3}$ \\ ${ }^{1 \& \# 3} \mathrm{PhD}$ Candidate in College of Public Administration-Huazhong University of Science and Technology \\ ${ }^{2}$ Supervisor and Professor in Public Policy Analysis, College of Public Administration- Huazhong University of \\ Science and Technology
}

\begin{abstract}
This paper attempts to highlight an important fact that is the post-colonial legacies and the role of military in the politics of Bangladesh which has brought forth a new debate of what elements imputed military in the politics of Bangladesh to take over the power of the state. The rise of the military in politics comes about not only because of the failure of the political institutions; it may also occur because of the natural disposition of army itself. This paper shows how they hampered the institutionalization of the civil military relations and the impediment of the institutionalization of the democracy. The real scenario of Bangladesh is that political leaders, civil-military bureaucrats, and businessmen are found engaged in serving personal group interests. In such a scenario neither military rule nor civilian rule would make any qualitative difference; and thus political stability and economic development would never be achieved. The main aim of this paper is to identify the causal relationship of post colonial legacies and the role of military in politics of Bangladesh.
\end{abstract}

Keywords: Post colonial legacy, Civil-military, Politics, Democracy

\section{Introduction}

The post colonial legacies and the role of the military in the politics of Bangladesh is an essential part of political reading. Notwithstanding the fact that there is a global trend of military withdrawal from politics after the democratic upheaval of the nineties, the military continuous to play an important role in notion states of the east as well as the west. As we all know, the military has been at the saddle of power in most of the Third World countries through the second half of this century. Changes in the global scenario did much to lessen the military's role, but only to a certain extent the military's sphere of influence in statecraft is very strongly felt in states like Myanmar, Indonesia, Nigeria, Algeria and Turkey. It is a common understanding that military might is right even today though there are some changes in the patterns and approaches. Bangladesh is a new nation, though it is an old society with a democratic tradition. Like many other Third World countries, Bangladesh opted for a parliamentary system of government following independence in 1971. But the experiment is short lived. The failure of the political elites, weak political institutions, economic crisis and widespread corruption paved the military's road to power. After coups and countercoups, General Ziaurrahman, the than army chief, emerged as the strong man in the later part of 1975. This change in the leadership heralded the end of the role of politicians and a beginning of military predominance in the political life of Bangladesh.

This study will enable us to understand the context and circumstances in which military intervened and the manner in which in consolidated its position and brought institutional changes to legitimize its role of the military in the Third World countries, but no significant work on the post colonial legacies and the role of military in the politics of Bangladesh has yet been done. This study is expected to somewhat bridge the gap.

\section{Operational Definitions}

2.1. Colony:Generally the term colony comes from the Latin word colonies, meaning farmer. A group of people living in such a country or area, consisting of the original settlers and their descendants and successors.

A body of people living in a new territory but retaining ties with the parent state

The territory inhabited by such a body. 
2.2 Colonialism: Colonialism is a practice of domination, which involves the subjugation of one people to another. Colonialism indicates political and economic control over a dependent territory.

2.3 Post Colonialism: Post colonialism is the study of the legacy of the era of European, and sometimes America, direct global domination, which ended roughly in the mid $20^{\text {th }}$ century, and the residual political, socio- economic, and psychological effects of that colonial history.

2.4 Military: A group of armed forces who are engaged in safeguarding the country from external occupation

2.5 Politics: Politics denotes a kind of activity associate with government, but there are conflicting views as to what this activity amounts to. Politics can be simply defined as the activity by which differing interests within a given unit of rule are conciliated by giving them a share in power in proportion to their importance to the welfare and survival of the community.

\section{Objectives of the study}

To find out the extent and compulsions that motivated the military to take over political power in Bangladesh.

To explore the prospects and impediments of democracy and the challenge of development

\section{Theoretical Frameworks and Research Methodology}

4.1 Research Methodology: A methodology refers to the choices we make about case to study methods of data gathering, forms of data analysis etc, in planning and executing a research study (Silverman, 2001:4). Since sociology usually seeks to investigate the question "why, how?" of social phenomena, different types of methodologies need to be adopted for different types of investigations.

In conducting a research on a certain problem or issue, a researcher has to adopt some methods and techniques. The logic of adopting certain methodological approach depends on the nature and purpose of the study.

4.2 Technique of Data collection:/Role of Documentary study: In this research work, researcher has employed the documentary study to find out the post colonial legacies and the role of military in the politic of Bangladesh. Documents, both historical and contemporary, are a rich source of data for social research.

4.3 Methods of Data Collection and analysis:As this research is historical based so researcher has followed documentary data and secondary analysis for ensuring the validly and reliability of this research. Researcher has followed "access" (Scott's typology of documents, 1990) of open published documents and has given attention in secondary analysis.

The importance of secondary analysis is growing in qualitative research. To conduct this research researcher considered various types of documents as a data which are collected by national and international books, newspaper, journals and articles. In this study researcher has tried to put up with all types of impediment to maintain ethical consideration of research.

\section{Liberation Struggle: Level of Politicization}

The prolonged Liberation War of nine months may be divided into three phases. The first, which may be termed as the conventional resistance, was an offshoot of the post-colonial army traditions. It consisted of the regular Bengali Units guided by a conventional approach to military matters. This group is best represented by Majors Shafiullah, ZiaurRahman and Khaled Mosfiarraf who became top-level sector commanders and, above all, by Colonel M A G Osmany, who was appointed the chief of Liberation Forces by the Awami League government in exile. Their approach was to organize all the trained Bengali military personnel into conventional units which would operate from bases in India. Their goal was to achieve independence as soon as possible by fighting against the enemy conventionally, in collaboration with the Indian Army.Scholars admit that the roots of the political role of the army lay in the Liberation War. In other words, "for historical reasons, we have to analyze the situation during the liberation period for understanding the role of the military in politics (M.Rafiqul,1989:3). We can categorize the 
causes and level of politicization in three manners: (a) Politicization by circumstances, (b) Politicization by the Liberation War and (c) Politicization through the political process.

A case Study of Politicization: (Sector Commanders in teh Liberation War)

\begin{tabular}{|c|c|c|c|c|c|c|}
\hline $\begin{array}{l}\text { Sector } \\
\text { No. }\end{array}$ & Sector Commander & $\begin{array}{l}\text { Last } \\
\text { position } \\
\text { held }\end{array}$ & $\begin{array}{ll}\text { Process } & \text { of } \\
\text { relinquishment } & \end{array}$ & $\begin{array}{l}\text { Political } \\
\text { identity }\end{array}$ & End of life & Remarks \\
\hline \multirow[b]{2}{*}{1.} & $\begin{array}{l}\text { ZiaurRahman, } \\
\text { BirUttam }\end{array}$ & Lt. General & Normal Retirement & $\begin{array}{l}\text { Founder } \\
\text { chairman BNP }\end{array}$ & Assassinated & $\begin{array}{l}\text { President of the } \\
\text { Republic 1975- } \\
81\end{array}$ \\
\hline & $\begin{array}{ll}\text { Rafiqul Islam, } \\
\text { BirUttam }\end{array}$ & Major & Self retirement & Anti-Zia & & $\begin{array}{l}\text { Now a minister } \\
\text { in AL Govt. }\end{array}$ \\
\hline \multirow[b]{2}{*}{2.} & $\begin{array}{l}\text { KhaledMosharraf, } \\
\text { BirUttam }\end{array}$ & Brigadier & & Al Leaning & Killed & $\begin{array}{l}\text { Leader of the } \\
\text { Nov } 3,75 \text { coup }\end{array}$ \\
\hline & 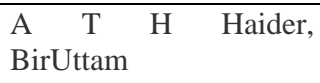 & Colonel & & Not known & killed & $\begin{array}{l}\text { Close associate } \\
\text { of Khaled }\end{array}$ \\
\hline \multirow[b]{2}{*}{3.} & $\begin{array}{lcl}\text { K } & \text { M } & \text { Shafiullah, } \\
\text { BirUttam } & \end{array}$ & $\begin{array}{l}\text { Major } \\
\text { General }\end{array}$ & Resignation & $\begin{array}{l}\text { Al Leader and } \\
\text { MP }\end{array}$ & & $\begin{array}{l}\text { Ambassador } \\
\text { during Zia and } \\
\text { Ershad regimes }\end{array}$ \\
\hline & ANM Nuruzzaman & Lt. Col & Self retirement & Left learning & & $\begin{array}{l}\text { Involved in } \\
\text { group politics }\end{array}$ \\
\hline 4. & C R Dutta, BirUttam & $\begin{array}{l}\text { Major } \\
\text { General }\end{array}$ & Normal Retirement & AL leaning & & $\begin{array}{l}\text { Involved in } \\
\text { sectarian } \\
\text { politics }\end{array}$ \\
\hline 5. & $\begin{array}{l}\text { Mir Shawkat Ali, } \\
\text { BirUttam }\end{array}$ & Lt. General & Forced retirement & BNP & & $\begin{array}{l}\text { Minister Under } \\
\text { Khaleda Zia }\end{array}$ \\
\hline
\end{tabular}

\section{Political Rules of the Military in Third World}

TABLE 6.1: Period of Military Rule as Percentage of Total Years of Independence

\begin{tabular}{|c|c|c|c|c|}
\hline $\begin{array}{l}\text { Name of } \\
\text { Country }\end{array}$ & \begin{tabular}{ll}
\multicolumn{1}{c}{ Years } & of \\
Independence up to \\
1984
\end{tabular} & \begin{tabular}{|c|} 
Years \\
Military Rule
\end{tabular} & Rule ${ }^{\text {Years of Civilian }}$ & $\begin{array}{l}\text { Military Rule as a } \\
\text { percentage of Years of } \\
\text { Independence }\end{array}$ \\
\hline Algeria & 23 & 20 & 3 & 87 \\
\hline Bangladesh & 14 & 9 & 5 & 65 \\
\hline Benin & 25 & 18 & 7 & 70 \\
\hline Burma & 37 & 25 & 12 & $\ldots \ldots$ \\
\hline Burundi & 23 & 19 & 4 & 82 \\
\hline \multicolumn{2}{|c|}{ Central African Republic 25} & 18 & 7 & 70 \\
\hline Chnnd & 25 & 9 & 16 & 38 \\
\hline Congo (Republic) & 25 & 17 & 8 & 67 \\
\hline Equatorial Euinea & 17 & 12 & 5 & 69 \\
\hline
\end{tabular}

\section{Political roles of military in Bangladesh}

The Two Military Regimes (Zia and Ershad as Military Rulers)

There are as many similarities as there are differences between the two military rulers and regimes which governed Bangladesh for nearly fifteen years of its existence. Zia ruled from 1975 to 1981 and Ershad from 1982 to the end of 1990. Both men represented the military as Chief of Army Staff when they took over the power of the state, and neither had the legal or moral authority to do so. Although the background and 
circumstances were different,both involve the military in politics, governed the country under Martial Law decrees with total disregard for human rights, disrupted Constitutional rule, stifled civil administration and courts of judicature and established themselves as rulers by decree rather than consent.

Both men were basically military officers who facilitated the consolidation of the civil-military bureaucracy and relied more on the bureaucrats than politicians to administer the country. The power of governing the state moved from the hands of the politicians to the combined class of officers and technocrats which changed the character and complexion of the administration as a whole.

The long period of rule with an unrepresentative government about four years in the case of Zia and another four years in the case of Ershad - when the country was ruled under Martial Law and there was no participation by the people, destroyed the growth of democratic institutions, a disruption from which for a nation like Bangladesh it was difficult to recover. The nature of the military regimes and the way they emerged ensured that democracy could not blossom among a people who had fought a war to achieve it. Zia and Ershad had more or less the same socio-economic philosophy.

Both regimes contributed to the emergence of a class of military personnel who would influence the course of the nation. The economic policies of both regimes led to the allocation of funds for cosmetic developments and for the unproductive sectors, leaving the fundamental issues such as literacy, population growth and poverty alleviation virtually unattended. On the contrary, unemployment, illiteracy, landlessness and mass deprivation increased in proportion to the growth in population.

The route to civilianization followed by both Zia and Ershad was similar to that of many other military regimes. When they realize that they can no longer run the country under Martial Law, military rulers who want to perpetuate their power opt for a civilian course to legitimize their rule. In almost every military ruler there develops an ambition to be a man of the people and to govern the country with the support of the people.

Both Zia and Ershad used the provisions of the Constitution literally, exercising all possible powers and disregarding any thought of developing a system of checks and balances or sharing power with others. Neither of them believed in encouraging democratic norms and practices centering round the office of the President. Both were dictators, ruled the country single-handedly and made maximum use of the authority given by the constitution. The rise to autocracy and dictatorship in Bangladesh emanated from the constitutional system introduced earlier by Sheikh Mujib and later recreated by Zia and practiced by both Zia and Ershad.

Of course there were differences between the two regimes in style, character, quality and performance. Zia's take-over was not like that of Ershad, who staged a cool, calculated, conventional, bloodless coup. Zia emerged more as a hero, when the troops and people joined hands to install him in power. Although he was the Chief of Army Staff, he neither moved with the army as an institution to take over power, nor did he remove an elected government to usurp authority. Zia did not propagate any political role for the military in the administration of the country nor did he have to proclaim Martial Law. With the tragic killing of Sheikh Mujib and his family, the whole character of national politics changed and this unforeseen moment of change resulted in Zia's advent to power. The complexities arose from a situation which saw divergent political forces trying to fill the vacuum left by Sheikh Mujib.

\section{The factors leading to politicization}

As an institution, the military has a variety of reasons for seeking a political role. These can be grouped under four main headings:

(a) Maintenance of or increase in military's share of national resources:

It seems likely that dissatisfaction with the share of national resources devoted to military purposes is more a contributing factor to than the sole cause of military involvement in the political process.

(b) Maintenance of the integrity of the armed forces:

Military officers are antagonistic to any attempt to remove from them the responsibility for internal military matters such as promotions appointments or punishments. When conflicts arise between military and political leaders, the latter often seek to strengthen their position by manipulating promotions and appointments, forcing particularly strong opponents within the military into early retirement or sending them on missions abroad. Both 
the manipulation itself and the attempt to alter the ideological make-up of the officer corps are resented and may encourage officers to take some sort of action against the politicians.

(C) Fear of national disintegration: Military officers frequently say that they are required to intervene in politics especially to take over the government because civilians have proven inefficient, corrupt and generally incapable of government and the country is, as a result, plagued by widespread social, economic and political disorders. It is perhaps self-evident that military intervention is considerably easier to effect in the absence of a strong, popularly elected civilian-dominated government.

(d) Expansion of the concept of 'national security: One direct and extremely important result of the military's fear of political and economic liberalization has been the expansion of the concept of national security to include internal security.

\section{Political roles of military in Bangladesh}

A high level of politicization of the armed forces in Bangladesh is evident. The pre-dawn coup on 15 August 1975 by a handful of junior officers ( 20 to 25 majors and captains) with the help of two battalions of the armored corps of the Bangladesh Army and supported by a regiment of soldiers with a strength of about 1400 was the first indication of their overt intention to take over. The August 1975 Coup, which resulted in the violent death of Bangabandhu Sheikh MujiburRahnjan, the constitutional head of the State, along with all the members of his family except his two daughters who were away from Bangladesh at that time, was closely, followed by a series of coups and counter-coups until 30 May 1981 when General ZiaurRahman, another constitutional head of Bangladesh., was brutally killed by a group of 20 to 22 military officers at Chittagong circuit house in another abortive coup. Bangladesh was under Martial Law for the second time under the leadership of Lieutenant General H.M, Ershad from 24 March 1982 to 11 November 1986.

The process of politicization of the armed forces in the post colonial state of Bangladesh is linked with the organizational framework of the military in British India and orientation of its officer corps. In the Western countries the concept of military as a politically neutral body has emerged mainly because of the fact that the democratic institutions have evolved over a longer period of time with the least involvement of the military. The primary role of the British Indian Army was to maintain law and order and internal security. The colonial regime effectively realized their goal through the deployment of a regiment of predominantly one religious, linguistic or regional affiliation in a region of a predominantly different religious or linguistic affiliation.

\section{Post Liberation Period}

Present state of Bangladesh Military

Bangladesh society is largely hierarchical, with regard to traditional Islamic values. During the time of 1971, the then East Pakistan society had a huge class differences.

From that time social needs have increased to a large extent. The higher social needs and availability of modern facilities have attracted the most population of Bangladesh resulting to run after the materialistic opportunities and immoral activities. Members of the army are no exception to it. With the involvement of the army time and again during political crises and employing them frequently for IS duty has put the credibility of the organization at question especially to the political workers and civil societies.

This also contributes in demoralizing and derailing the members of the Army. The social changes, political and incautious employment have contributed negatively in the discipline, morale, and patriotism. Over the years Bangladesh Army has experienced lot of changes, may have which have contributed negatively to weaken the organization. The new generation soldiers lack the spirit of liberation war. Most of the members of the armed forces have inclination to materialism. The materialist feelings are decaying of social and moral values of the armed forces. The political instability in Bangladesh requires frequent deployments of the army to support civil authority. Bangladesh army has been doing the job for many years since the independence. Frequent and long term deployment outside, creates problems in terms of trading, administration and motivation. Independent political activities by the military have been wide spread and of long-standing. Many retired officers have joined 
different political parties. Few of them have ruled the country for years. There are some people who maintain their allegiance with the political parties.

These kinds of activities have contributed negatively to the motivation of the army. The role of military in politics has got a new shape that makes the position of army in critical nature in politics. For the infirm interpersonal relationships between the junior and senior officers and relationship gapes among officers and the other ranks creates mistrust and may lead to crisis. Beside these, the lack of co-operation and mutual trust between the members of the army, lack of consciousness about the affects of colonial legacy, lack of loyalty to the command and to the government, lack of political and populous support for a military personnel to become a strong member in political arena make the critical state to play the vital role for military in politics.

Findings and Conclusion

A discussion on post colonial legacies and the role of military in the politics of Bangladesh would reveal that military intervention in the countries politics had been the outcome of a number of factors the major one being the colonial legacy. The terrible failure of political leadership in state management is also another cause of military intervention. Not only the special organizational characteristics of the military and their corporate interest, but the performance failures of civil authorities, which are due mainly to societal forces, have also to be considered as explanations of military intervention in politics. The question is that have there any relationship between colonial legacy and military intervention in national politics. In order to answer this question this study shows that Bangladesh army, which was the lineal descendent of the British Indian and Pakistan Army, inherited not only the institutional frame work of their predecessors but also acquired the values, believes, customs, norms and ethos especially their orientation and at the same time their consciousness of political power. In the post colonial states like Bangladesh the military tend to be dominated not only because of these states inherit an over developed organizational frame work and its institutionalized practices, as suggested by HamzaAlavi. Organization provides the armed forces with discipline and cohesion, hierarchy and centralized command, and the institutional positions give them power. It is no wonder, therefore that the military elite in a post colonial state like Bangladesh become a dominant force. More uses of military in state affairs create opportunity for military to take over the power in the state. In order to give the answer of why and how the military intervened in Bangladesh polities it can easily say that corporate interest of the military however have always been the chief motivating factor for intervention. To explore the relationship between the legacy and the role of military in the politics of Bangladesh it is evident that from the very beginning of the Bangladesh Army, the tendency was to follow the structural pattern of the Pakistan army as well as it values and traditions.

\section{Acknowledgements}

I am very grateful to my $\mathrm{PhD}$ supervisor Professor Wang guo hua and one of Younger brother named Toriqul Islam who give me lot of information regarding this paper

\section{References}

[1] Ahmed, Eqbal, 'Political Culture and Foreign Policy: Notes on American Intervention in the Third World' in Allen F. David (ed.) For Better or Worse: The American Influence in the 14"orld (Greenwood Press, London, 1981).

[2] Ahmed, Emajuddin, Military Rule and Myth of Democracy (UPL, Dhaka,1988).

[3] (ed) Society and politics in Bangladesh (Academic Publishers, Dhaka,1989).

- 'Crisis of democracy in Bangladesh', Bangladesh Today, vol 2, No 16, March 1-15,1989.

- Development Strategy in Bangladesh: Probable Political Consequences, Asian Surveyvol 18, No 2, November 1987.

- $\quad$ Military Elite and Their Development Role, Asian Affairsvol 1, No 1, 1980.

[4] Ayub, M, 'The Military in Pakistan's Political Development: Its Growing Strengths and Implications, South Asian Review, Vol 7 No 1, January 1972.

[5] Balerow, Davis B, 'The Civic Role of the Military: Some Critical Hypothesis' Western Political Quarterly 1 9(1) March, 1966.

[6] Frank, Andre Gaunder, Crisis in the Third World (Holmes and Meier, London, 1981). 
[7] Ghoshal, Baladas, Indonesian Politics', 1955 - 59: the Emergence of Guided Democracy (KP Bagchi and Co. Calcutta, 1982).

- 'The Military and Politics: A Review Article,' Contemporary South East Asia. September 1986.

[8] Gill. Veena. 'The Military in the Politics of Developing Nations: The Political Orientation and involvement of the Indonesia Military 19451978 IDSA Journal 1983(New Delhi)

[9] Cohen, Stephen P. The Indian Army: Its Contribution iv the Development of a Nation (University of California Press, Berkley, 1971).

- Arms amid Politics in Bangladesh, India and Pakistan (Council on International Studies, State University of New York, Buffalo), 1973).

[10] Hoffman, Stanley, 'Heroic Leadership: The Case of Modern France,' in LewsEdinger (ed.) Political Participation in Industrial Societies (John Wiley, New York, 1967).

[11]Hopkins, K, 'Civil-Military Relations in Developing Countries,' British Journal of Sociology, Vol 17, No 2, June 1966. https://doi.org/10.2307/589055

[12] Huntington, S P. The Soldier and the State: The Theory and Politics of Civil Military Relations (Belknap Press, Cambridge, 1957).

- (ed.) changing Patterns of Military Politics (Free press, New York, 1962).

- 'Political Development and Political Decay,' World Politics 17(3) April, 1965.

- Political Order in Changing Societies (Yale University Press, New Haven, 1975).

[13]Lisaak, Moshe and William Gutteridge, 'Modernization and Role Expansion of the Military in Developing Countries Comparative Studies in Society and History, No 9, 1966.

[14]Lukham, R, 'A Comparative Typology of Civil-Military Relations, Government and Opposition 6(1), Winter I 971, -Militarism: Force, Class and International Comfliet,' ISD Bulletin, Vol 9, No 1, 1977.

- 'Militarisms and International Dependency: A Framework for Analysis,' in J JVillamil(ed.), Transitional Capitalism and National Development (Harvester, Sussex, 1979).

[15] Maniruzzaman, Talukder, Military Withdrawal from Politics: A Comparative Study (UPL, Dhaka, 1989).

[16] Sisson, R, 'Politics and the Military in Pakistan' in J P Lovell (ed.). The Militia's and Politics in Five Developing Nations (Cress, Kensington. 1970). 